Article

\title{
Filmic Gendered Discourses in Rural Contexts: The Case of the Camino de Santiago (Spain)
}

\author{
Lucrezia Lopez $(\mathbb{D}$
}

Department of Geography, University of Santiago de Compostela, 15782 Santiago de Compostela, Spain; lucrezia.lopez@usc.es

Received: 29 May 2020; Accepted: 18 June 2020; Published: 22 June 2020

\begin{abstract}
Rural areas have turned into multifunctional areas. They satisfy different economic and social requirements; among these, they are consolidating their position as film production locations. Becoming a film location ensures visibility and provides new forms to access sustainable economic trajectories to promoting rural areas and rural vitality. In some cases, filmic discourses present unequal gender treatment that may be associated with their locations. Considering this, the aim of this research was to explore cinematic discourses based on the symmetry or asymmetry in gendered cinematic representations that mainly occur in the rural space of the Camino de Santiago (Spain). This First European Cultural route crosses urban and rural centers that have benefited in different ways from its international recognition. By combining both the linguistic and visual codes, I engaged in a qualitative film discourse analysis concerning female pilgrims along the route. Despite of the feminization of the Camino, the results prove the permanence of gendered norms and societal roles in audio-visual productions based on a common latent ideology. The conclusions introduce the concept of social and relational sustainability as a way to achieve equal gender treatment when creating media discourses.
\end{abstract}

Keywords: cinema; filmic discourses; rural areas; landscapes; gendered interpretation; territorial identity; Camino de Santiago; sustainability

\section{Introduction}

Creative and cultural media are common communicational tools conveying social and cultural messages; their content is diverse and affects the perceptions of their targets, contributing to the production of gendered cultural identities [1-3]. Among them, the focus of this study was movies, which are assumed to be cultural documents and social sources of information, whose spaces can be unconsciously elaborated $[4,5]$. The audiovisual industry has become increasingly interested in cultural routes because their landscapes provide authentic locations for film productions that, as a result, share territorial, visual, and textual discourses [6]. The cinema serves as a form of promotion and can lead to local development due to all the associated activities [7]. In this context, rural areas are unique scenarios for cinema, providing an opportunity to enhance their territorial identity due to its popularity. Therefore, film-induced tourism can play a pivotal role in promoting endogenous local economic awakening of selected rural areas [7,8]. For rural communities, becoming a film location can be a method of reinterpreting their vitality; due to the positive impacts of this growing creative industry, these locations may plan new sustainable economic trajectories by participating in an innovative and collaborative development model. The cultural and creative audiovisual industries satisfy different aims, as they can contribute to promoting the values of the territory identity elements; all of them ensure visibility while contributing to the construction of attractive and unique tourist rural spaces $[9,10]$. For this growing importance, the present research draws attention to the production of 
filmic discourses, both textual and visual, associated with the rural context of the Camino de Santiago (Spain) (henceforth the expression used will be the Camino).

The Camino is the First European Cultural route, and one of the most important pilgrimage routes in the world. Its origin dates back to the 9 th century, and follows the discovery of the remains of the body of the Apostle St. James, an event known as the inventio (that is the discovery of the relics of a martyr in a place where there is no previous tradition of their existence), and their official recognition in the 12th century [11]. The Camino is used to refer to a network of routes walked or ridden by a large number of pilgrims to travel to a small city in the north of Spain: Santiago de Compostela. These routes would bring thousands of people from all over Europe; that is why the Camino played an important role in the construction of Western European culture during the Middle Ages; as Goethe once stated, "Europe was made on the pilgrim road to Santiago de Compostela". A major pilgrimage movement emerged, reaching its heyday in the 12th and 13th centuries [12]. After many years of intense pilgrimage movements, in the 15th century, the number of pilgrims walking the routes to Santiago de Compostela started to decrease, and the pilgrimage to St. James entered into a continuous decline, which lasted until the 19th century [13]. The urban historical center of Santiago and some routes of the Camino have been appointed as UNESCO World Heritage Sites (WHS). In 1993, the French route was first declared a WHS; then in 2015, the northern routes (consisting of four routes: the Original Camino, the Coastal Camino, the Basque Country-Rioja Inland Camino, and the Liébiana route) received the same international accolade. Since 1993, the Camino has been strongly promoted by the regional government. This process of recovery was conceived as a path to the socio-economic enhancement of the rural space [14]. Many of the actions aimed at conditioning the rural areas of the Camino were financed by the Structural European Funds LEADER I and II (the French acronym stands for: "liaison entre actions de développement de l'économie rurale", in English it means: links between the rural economy and development actions) and PRODER (Operational Programme of Development and Economic and Economic Diversification of Rural Areas) $[15,16]$. Since then, the Camino pilgrimage space has assumed a tourist function [17]. The necessary services, infrastructure, and equipment (for instance, hotels and public hostels) have been constructed and provided along the route [18,19]. In the following passage, Rubén Lois González and Xosé Santos Solla [20] summarize the main changes occurring along the route: "old paths and walkways have been repaired, bridges have been rebuilt, water sources have been purified, ancient monuments and populations have been regenerated and repopulated, native trees have been planted and signs have been placed in a set of repeated cultural or pilgrimage itineraries" (p. 5). Indeed, the 1993 Holy Year (the Holy Jacobean Year is essentially a Jubilee year, which only covers the city of Santiago de Compostela. It is also called Jacobean Years and is celebrated every 6, 5, 6, and 11 years when the feast of Saint James on the 25th of July falls on a Sunday) marked the conversion of both Santiago and the Camino into major Spanish and international tourist destinations [14,18]. This Plan Xacobeo 93 led to the take-off of the tradition of pilgrimages to Santiago, assumed as the most well-known brand in Galicia and easy to sell on the European and world markets. Since that year, the Holy Years have turned Santiago and the Camino into two of Spain's most popular tourist destinations [12,19]. As a consequence, the growth in the number of pilgrims arriving to Santiago has been continuous, from 99,436 in 1993 to 347,578 in 2019 [21]. This is due to the fact that the city of Santiago and the Camino have turned into a polysemic space in reference to the plurality of meanings, functions, and motivations that nourish these spaces [17,21,22]. Motivation is one of the fundamental elements of the Jacobean pilgrimage [12]. Nowadays, the most common spiritual motivation is embodied in items such as "health", "religious motivation" or "pilgrimage", so the Camino is a sort of therapeutic route [23], as the movies will show. In fact, as in reality, the characters will do it for a "keen realization of personal wounds or missing elements in one's everyday life. Divorce, death, losing one's job, alienation from one's body, work, self or society are often the reasons for these wounds or lacks. The second element consists in experiences of renewal or transformation. Therapy as it is experienced on The Way is very often a gradual process in which you open up to the suffering in your soul while you move" [24] (p. 267). The Camino clearly 
offers experiences related to emotions, and perceived spirituality is linked to the visited environment, as well as to the emotional processes experienced during the journey.

Until now, few studies have explored the relationship between the Camino and cinema [25-29], and none has investigated this issue in gendered terms. Their interest mainly focused on considering cinema as a touristic resource that is able to project a local image onto an international scale. However, with this research, I aimed to examine movies as sources of information providing patterns about social and cultural behaviors so as to renew the dialogue between cinematic production and gendered roles along the pilgrimage route, which is mainly characterized by rural areas. As gender analysis in tourism can focus on one or both sexes to explore the social construction of roles and behaviors [30-32], the research aimed to reveal the way in which behaviors and roles respond to social constructions of gender. The aim of this study was to reconstruct a cinematic discourse based on the symmetry or asymmetry in gender cinematic representations that mainly occur in the rural space of the Camino. The paper is structured into four sections. Section 2 provides a brief literature review concerning the key theoretical pillars of the paper: cinema and gender. Since film language is complex, this paper proposes one of the possible movie interpretations that works as an interpretative hypothesis of the work [33]. To this purpose, Section 3 presents the qualitative approach that was used to highlight the cultural and ideological components and the social relations. Section 4 presents the resulting interpretative activity that supports the existence of a latent ideological framework that might be associated with this space, producing impacts and effects on a target public, which is becoming increasingly interested in productions related to the Camino. The findings highlight the concept of social and relational sustainability as a way to achieve equal gender treatment when creating media discourses, as pointed out in the final Section 5 .

\section{Literature Review}

According to Bernard Lane [34], rural tourism includes "farm-based holiday but also comprises special-interest nature holidays and ecotourism, walking, climbing and riding holidays, adventure, sport and health tourism, hunting and angling, educational travel, arts and heritage tourism, and in some areas, ethnic tourism" (p. 9). In addition, rural tourism deals with the recovery of traditional architectural heritage, the management of natural and cultural resources, and the involvement of the local population in tourism development, and is motivated by the pursuits of tourist attractions associated with relaxation, countryside, traditional culture, and escape from everyday life $[35,36]$. Thus, considering these multiple activities and motivations, walking the pilgrimage route can be considered an alternative form of rural tourism; apart from the pilgrimage infrastructure, pilgrims use rural tourist facilities. Pilgrims spend a good part of their time walking through different rural landscapes. Both pilgrimage and rural tourism are aimed at increasing the positive social, economic, and environmental impacts of tourism [37]. Due to the rich natural and cultural heritage that can enhance territorial identity and create an attractive brand for the territorial competitiveness [38], Camino rural landscapes are ideal locations for narrations of personal problems and concerns, feelings and emotions, and hopes and expectations. Given these premises, the present section provides a brief review of the key theoretical pillars of the paper: cinema and gender. This choice is justified because the cinematic sources are used here as the main research material, and gender is the interpretative theorem of the selected sources.

\subsection{Cinema}

When talking about cinematic languages and productions, different positions and schools of thinking can be traced. George Friedmann and Edgar Morin [39] stated that all movies must be considered as keys to understanding and accessing the dark spaces of society. The cinema is co-created together with its public through the production of images, which might be assumed to be forms of knowledge of reality. A movie undergoes different interpretations that result from constraints defining the register and the genre of the critic, and thus of its public. Spectators are an important part of 
the meaning-making process of a movie, as they are part of this act of communication. Originally, according to the French film theorist Christian Metz [40], the founder of film semiology, films cannot be regarded as comprising a language composed of strict grammar and syntax like the written or spoken word. In C. Metz's opinion [40], a film's basic unit is the shot, which is neither symbolic nor arbitrary but iconic; therefore, it is laden with specific meaning. Considering this, a movie is a language that involves a large number of signifying organizations that are linked to perception, imagination, social, intellectual, and ideological position. In his theoretical model, known as the "grande syntagmatique", C. Metz [40] argued that individual cinematic texts construct their own meaning systems rather than sharing a unified grammar.

According to the German film theorist Siegfried Kracauer [41], cinema is unique as it establishes a permanent tension between reality and creation. Even the most artificial movie creation expresses a certain epoch and a certain culture. For this reason, he stated that cinema is a documentary that reflects the status of the real world. Conversely, the French philosopher Edgar Morin [42] believed that the movie is not a direct reflection of the social world; rather, it is an object to analyze in itself, between the everyday and fantastic world, truth and illusion. Thus, it is an object with a double nature, both real and imagined. Cinema presents institutional and sociological issues, but also acts as an institution of social imaginary. E. Morin [42] stated that one of the main aspects of cinema is the public, which reminds us that the cinema is a social engine aimed at cultural consumption. A further position about the degree of realism within cinema is that of the French film critic Pierre Sorlin [43], who argued that cinema is a translation of reality that works on the basis of a levy operated on the world, which is enabled by the tools and techniques of each movie. In other words, he stated that cinema is a translation of the real world that acts like a repertory and producer of images that projects that fragment of reality accepted and recognized by its public [44].

Considering these different positions, cinematic productions narrate stories and describe places and locations, lifestyles, customs, and practices. In other words, they participate in the creation of a territorial discourse that might seduce millions of spectators and contribute to the diffusion of different social habits and behaviors, apart from being a tool for promoting natural and cultural environments. Due to their communitive function, movies facilitate the diffusion of cultures and create an image of a destination [8,27]. As such, they produce a visibility, reinforcing the territorial soul and uniqueness and increasing international popularity [36-39]. Cinematic images can reproduce emotional journeys (experiences, vision of places, and scenic beauties), thus affecting the decision to undertake a trip [45-51]. Due to this enhancement of human and spatial relationships, cinematic productions can disclose affective aspects of the places, creating geography of experience and even imaginary geographies [52,53].

Among the emerging factors relating the cinema with the rural area is the rural landscape perception. Since the end of the 20th century, the perception of rural areas as part of the open spatial system has grown [54], and cinema is one of the industries that are incorporating this trend due to its visual and scenic properties. Perception and interpretation come together in the domain of visual ideology and the spectacularization of life in Western culture, with the eye as the only means to acquire knowledge [55,56]. It is possible to distinguish between an outsider and an inner cinematic landscape. In the first case, the cinematic landscape represents the territorial richness and the magic atmosphere of faraway places; in the second case, it refers to an experience based on the relationships between characters and space $[57,58]$. All of these elements result in the soft sale of the territory generated by movies. Due to the different techniques, movies appeal both to rational and to emotional elements; these elements interact to produce a representation of cinematic landscapes subjectively organized depending on cultural additions [59]. In terms of the case study, cultural itineraries mirror the territorial wealth of film productions, which are favored by the use of dynamic images. 


\subsection{Brief Review of Gendered Issues}

After the psychoanalytic hypothesis of Robert Stoller in 1968 [60], gender studies was a concept elaborated by Ann Oakley in 1972 [61]. Sex is a social category; men and women are social groups. With the term genre, Risa Whitson [3] defined it as "one of the primary ways in which our society produces and naturalizes differences" (p. 49); therefore, it is relevant for understanding culture. Gender studies are a way of approaching women and men as inseparable parts of a functioning system. They are based on a relational approach to sexes, according to which the features ascribed to each genre are socially founded on a relationship of opposition and complementarity [62]. Early studies of women and geography addressed differences between men and women in terms of work, pay, and societal roles [63]. Gender relations are constitutive of the spaces because our presence and behaviors within is gendered-determined, and spaces assist power relations that are traditionally constructed according to a masculine and heteronormative scheme [64]. From the point of view of the feminist geography, places are not harmonious, fixed, and static; rather, they are dynamic, socially constructed, fluid, and porous. Thus, spaces are generally considered "locations" where social and spatial relations occur, with interactions between them to produce a certain interpretation [65]. In some spaces, the patriarchal norms are more evident [65]. In Theorizing Patriarchy, Sylvia Walby [66] identified six structures through which women are dominated: households, waged work, the State, violence, sexuality, and cultural institutions (the media). As far as this last aspect is concerned, in the past, the cinema has been a "place" of research for the relationships between men and women, relatives and children [67]. Molly Haskell [68] showed that cinematic productions convey a certain kind of female representation evolving throughout time. In her opinion, the cinema naturally serves a singular ideology that tends to maintain the superiority of the male status; thus, spaces can be gendered through images that stress the women's subordinate status and reinforce masculinity [69]. This evokes the role of the male gaze; Laura Mulvey [70] stated that: "in a world ordered by sexual imbalance, pleasure in looking has been split between active/male and passive/female. The determining male gaze projects its phantasy on to the female form which is styled accordingly. In their traditional exhibitionist role women are simultaneously looked at and displayed, with their appearance coded for strong visual and erotic impact so that they can be said to connote to-be-looked-at-ness" (p. 19). She properly referred to how Hollywood narrative films used women to provide a pleasurable visual experience for men. This concept is related of Judith Butler's [71] notions of performative gender definition.

Following the so called "critical turn", tourism studies started to be interested in the analysis of the political and social dimensions of tourism, including the study of gender relations [72,73]. According to Karla Henderson [30,31], there are five stages defining the evolution of gender analysis in leisure studies that Margaret Swain [32] reinterpreted as follows: (1) invisible (without women); (2) compensatory ("add women and stir"); (3) dichotomous differences (sexual differences); (4) feminist perspective (focused on women); and (5) gender-aware frameworks (analysis of gender relations, roles and stereotypes that situate women in a subordinate position with regards to men). The progressive spatial feminization is changing other spaces into being woman-accessible. This is what can be appreciated in the case study. According to the statistical series published by the Cathedral of Santiago de Compostela, presenting the number of pilgrims collecting the Compostela (a certificate stating the completion of the pilgrimage having covered at least $100 \mathrm{~km}$ on foot or $200 \mathrm{~km}$ by bike or on horseback) at the Pilgrim's Reception Office in the Diocese of Santiago, there has been a general increase in the percentage of women pilgrims, as shown in Figure 1. The questionnaires by the Cathedral of Santiago and the resulting reports that, before the interruption of the activity due to the COVID-19, were regularly published on the webpage, provide different kinds of information, but the one regarding the pilgrims' sex was selected to point out a patterned increase in the female presences. Since data collection began in 2004, the percentage of female pilgrims had always been around $40 \%$. The only peaks occurred in 2004 and 2010, coinciding with the Holy Years. Since the last Holy Year 2010, the number of women heading to Santiago soared. Between 2011 and 2019, female participation increased by nine points and went from $42 \%$ to more than $51 \%$. This is interesting and relevant information, 
as it confirms a sort of feminization of the Camino, far from the past historical stereotypes according to which pilgrimages were undertaken by men $[74,75]$. This empowerment of the female pilgrims is irregular throughout the year. In winter the number of men is double that of women, and this might be due the fact that the most crowded months are perceived as the safer ones. In addition, these different behaviors might confirm what M. Swain [32] stated. In her opinion, women are involved differently from men in their consumption of tourism. However, at the present there is no study investigating this current trend, which might be due to different factors. Firstly, the post-contemporary space of the Camino is a "safe space", thus female pilgrims can walk alone. Secondly, the Camino welcomes people from different ages and cultures; it is an inclusive space, and thus it is also adequate for female pilgrims. Thirdly, and no less important, there is a democratization and equal access to cultural spaces, as the one of the Camino. These factors enhance the female participation in the pilgrimage, as, for instance, the same increasing female literary production of travel diaries is proving.

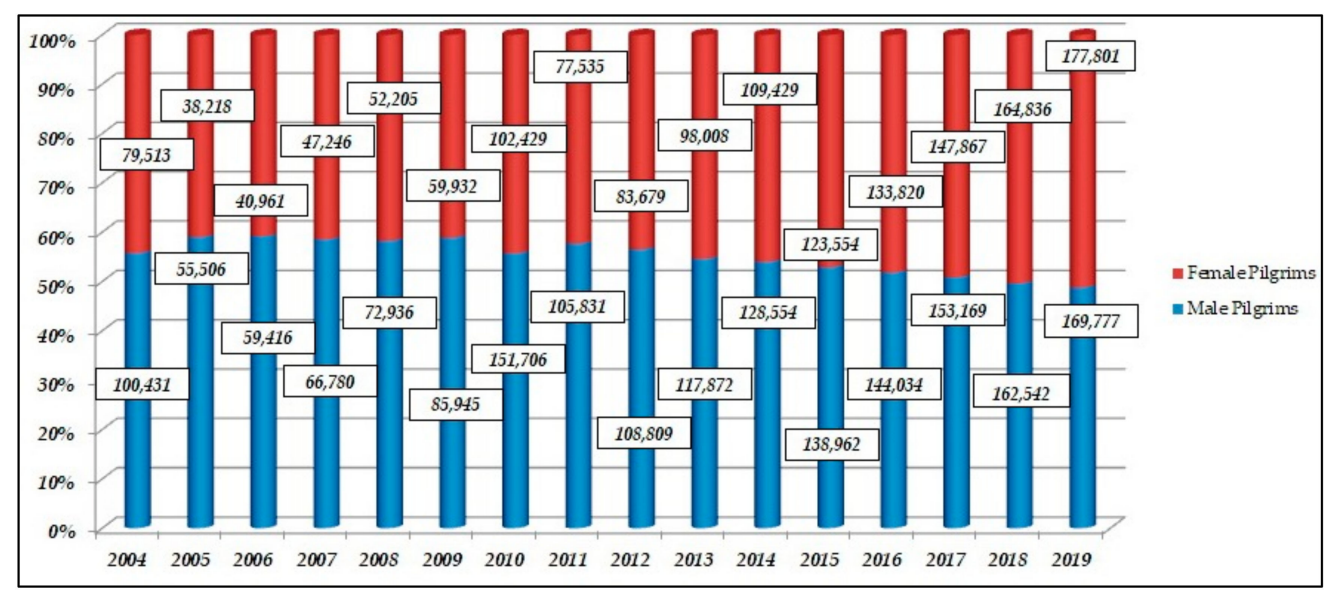

Figure 1. Pilgrims arriving at Santiago and collecting their Compostela according to their sex. Sources: pilgrims' reception Office (2004-2019).

\section{Materials and Methods}

Table 1 presents the main details of the selected movies: year and country of production, director, duration, the reason for doing the Camino, and the starting point. Concerning the motivation, the movies show post-contemporary pilgrims' motivations, as they point out the importance of living a unique experience with therapeutic effects, while enjoying landscape and environment, heritage and social relations $[20,23,24]$. These primary sources were selected according to the following criteria: (1) their location is basically the rural space of the Camino; (2) producers come from different countries: Saint Jacques ... La Mecque (France, C. Serreau, 2005), Al Final del Camino (Spain, R. Santiago, 2009), The Way (USA, Spain, E. Estévez, 2010), and Onde Está a Felicidade? (Brasil, Spain, C.A. Riccelli, 2011); and (3) they represent two different filmic genres: two comedies and two tragicomedies (thus determining different filmic discourses).

Table 1. The sources of the research.

\begin{tabular}{ccccc}
\hline $\begin{array}{c}\text { Movie } \\
\text { Details }\end{array}$ & $\begin{array}{c}\text { Saint Jacques ... } \\
\text { La Mecque }\end{array}$ & $\begin{array}{c}\text { Al Final del } \\
\text { Camino }\end{array}$ & The Way & $\begin{array}{c}\text { Onde Está a } \\
\text { Felicidade? }\end{array}$ \\
\hline Year & 2005 & 2009 & 2010 & 2011 \\
\hline Country & France & Spain & USA, Spain & Brazil, Spain \\
\hline Director & Coline Serrau & R. Santiago & Emilio Estévez & C.A. Riccelli \\
\hline Duration & $1: 45$ & $1: 37$ & $1: 22$ & $1: 42$ \\
\hline
\end{tabular}


Table 1. Cont.

\begin{tabular}{|c|c|c|c|c|}
\hline $\begin{array}{l}\text { Movie } \\
\text { Details }\end{array}$ & $\begin{array}{l}\text { Saint Jacques ... } \\
\text { La Mecque }\end{array}$ & $\begin{array}{l}\text { Al Final del } \\
\text { Camino }\end{array}$ & The Way & $\begin{array}{l}\text { Onde Está a } \\
\text { Felicidade? }\end{array}$ \\
\hline Reasons & $\begin{array}{l}\text { Get inheritance; } \\
\text { social experience; } \\
\text { personal (personal } \\
\text { thanksgiving) }\end{array}$ & $\begin{array}{l}\text { Magazine report; } \\
\text { solve couple crisis }\end{array}$ & $\begin{array}{c}\text { Personal (son's } \\
\text { death; work crisis; } \\
\text { search for new life); } \\
\text { sport }\end{array}$ & $\begin{array}{l}\text { Personal (search for } \\
\text { new life); produce } \\
\text { a reality show }\end{array}$ \\
\hline Starting point & Puy-en Velay & Galicia & Roncesvalles & Roncesvalles \\
\hline Male protagonist (s) & 5 & 1 & 2 & 2 \\
\hline Female protagonist (s) & 4 & 1 & - & 1 \\
\hline Male relevant characters & - & 6 & 2 & - \\
\hline Other male characters & 5 & 3 & 28 & 37 \\
\hline $\begin{array}{c}\text { Female relevant } \\
\text { characters }\end{array}$ & - & 4 & 1 & 1 \\
\hline Other female characters & 18 & 2 & 11 & 37 \\
\hline \multirow[t]{2}{*}{ Genre } & Tragicomedy & Comedy & Tragicomedy & Comedy \\
\hline & $\begin{array}{c}\text { Saint Jacques ... La } \\
\text { Mecque }\end{array}$ & Al final del Camino & The Way & $\begin{array}{l}\text { Onde Está a } \\
\text { Felicidade? }\end{array}$ \\
\hline
\end{tabular}

As each film's analysis was based on a filmic theorem, the interpretive act consists of setting a hypothesis and an interpretative work [76,77]. The interpretive theorem was the use of gendered stereotypes that (consciously or not) appear in the cinematic productions regarding the case study, whereas the interpretative work relied upon an inclusive multi-layered approach to obtain a critical understanding of power relations and social identities [76]. This interpretive procedure allows the identification and discovery of the potential of visive language when investigating knowledge and theories behind the camera. Thus, cinematographic images were compared to qualitative and social indexes that allowed the consideration of three components: (1) content-the plots are choices indicating the preferences of society; (2) style - the technical choices correspond to aesthetic selections; and (3) how to act in society-testimonies of social processes and dynamics [78,79]. Filmic decoding is aimed at drawing attention to the social and cultural aspects that are set together to characterize female pilgrims and their relations.

Upon these premises, this aim is achieved using a combined methodology based on the linguistic and visual analysis.

- Linguistic code: it shapes language and sexual identities as it plays an important role in the transmission of masculinity and femininity. Dinka Acevedo and Luz Gil-Salom [1] applied the methodology proposed by Theo Van Leeuwen [80] about social actors' representation to decipher how gender social conception is constructed by media influence (Appendix A). The roles of social actors play a significant part in the work of many critical linguists [80-85]. Since it is important to reflect on their roles in the cinema, the categories proposed by T. Van Leeuwen [80] in a critical analysis of racist discourse were selected to evaluate the cinematic critical discourse analyses. This approach is considered viable as the categories enable the identification of cultural and ideological ideas that structure the cinematic discourse set in rural space.

- Visual Code: Film is a narrative medium and an art based on language whose vocabulary is the simple photographed image [86]. Image is one of the most ancient and rich means of communication, whose reading must be considered an active rather than a passive exercise. For this reason, the analysis introduces meaningful images easily decoded by the public. Each visual analysis has its own methodology depending on the aims and the interests of the project [79]. Its immediate value is an ally for the dissemination and learning of customs and habits. For this reason, visual analysis was performed by introducing a selection of moviescapes representing female pilgrims in rural contexts. 
The preferences for these codes are justified by the intention to consider the most common and easily recognizable discourses related to cinematic production. Language and image are opposite and complementary codes, as language participates in the production of the visual content, reinforcing its message [79]. As stated by T. Van Leeuwen [80], "words provide the facts, the explanations, and the things that need to be said in so many words" (p. 136). They show until which point images can furnish imagination.

From an operational point of view, once the interpretative theorem was set and the sources selected, movies were watched using a media player reproducer, which made it possible to interrupt the projection when necessary to analyze the visual and linguistic content. Due to the multi-layered approach, movies were viewed several times. The first viewing was mainly conducted to understand the plot and to confirm the coherence of the selection of the sources; the views were repeated to "quantify" the information represented in the interpretative tables about the societal role associated with female pilgrims. Therefore, the number of projections changed according to the movies, as some needed more attentive analysis. This quantitative exercise necessitated counting, so a checking session was undertaken. The last projection was conducted to select moviescapes that satisfied the interpretative hypothesis of the research. This selection is introduced in the following section.

\section{Results}

This section is structured into four subsections, one for each movie. Each section presents the plot and the cinematic discourse analysis based on a selection of categories indicated by T. Van Leeuwen [80] and explained in Appendix A. Tables 2-5 and A1 refer to the cinematic discourse analysis of each movie according to T. Van Leeuwen [80] and present two main different social conditions: exclusion and inclusion. In the case of exclusion, only one technique is indicated; in the case of inclusion, a set of possible techniques conveys a different form of participation in the plot. To achieve this level of participation and involvement, attention was paid to reveal a different form of consideration. Here, the structuring of the cinematic discourse can be appreciated and evaluated. The quantitative information introduced in the table refers to those actors who are reproduced in the foreground (actors in panoramic and big collective scenes were not counted).

\subsection{Movie 1: Saint Jacques ... La Mecque}

In Saint Jacques ... La Mecque, the pilgrims' group is formed by nine pilgrims: the male guide and four male and four female pilgrims. They represent the French society through their different social statuses and religious professions. Clara is a teacher, who is obliged to walk the Camino with her two brothers (Pierre and Claude) to receive the inheritance from their mother, who faked her death in order to convince her children to go on the pilgrimage.

Following the Van Leeuwen [80] methodology, the social actors' representations can be classified as shown (Table 2):

- Backgrounding: Two out of four background female characters are influential: Clara's mother and Ramzi's mother. They determine much of the action. The former fakes her death to convince her children to undertake the pilgrimage and thus spend some days together; the latter paid for Ramzi's pilgrimage (supposedly to Mecca) because she wanted him to learn to read.

- Activation: The active social actors are mainly male characters, namely the guide, Pierre, Pierre's driver, and the notary. The active female social actor is Clara, who also works during her pilgrimage.

- Genericization: Social actors can be represented using generic references (classes). This classification occurs through individualization (spectators are informed about pilgrims' personal lives), aggregation (three male pilgrims), and collectivization (which refers to the group).

- Nomination: This mainly refers to the nine members of the group (who also undergo a process of collectivization) and their relatives. 
- Categorization: The three male characters are generally represented as priests, thus forming a category. Female categories are four nuns, three hosts, and six pilgrim officers.

- Functionalization: The male functionalized characters are the guide (throughout the film) and Pierre (who makes constant references to his managerial responsibilities). Both roles allude to a sort of sense of leadership (in the group and in the society). Clara teaches Ramzi to read.

- Identification: This process occurs through classification and relational identification. In the case of classification, the first criterion of classification is age. There is an equal distribution among the pilgrims: four men and four women, two adult men and two adult women, and two young men and two young women, although the guide is an adult man. A second identification is the religious belonging. Two boys are Muslim, three male social actors are Christians, and six women are Christian as they are nuns. Concerning class belonging, Pierre and Camille represent a rich social class. Claude is a poor alcoholic and Ramzi and Said are quite poor. Since the beginning, the filmic text is characterized by a relational identification. Pierre, Claude, and Clara are siblings. Then, there are Pierre' wife, Claude's wife and daughter, and Clara's husband, son, and daughter. The background female social actors are the brothers' mother and Ramzi's mother, as well as Camille's mother and the guide's wife.

Table 2. Cinematic discourse analysis of Saint Jacques ... La Mecque according to Van Leeuwen [80].

\begin{tabular}{|c|c|c|c|c|}
\hline & & & Female Characters & Male Characters \\
\hline Exclusion & Background & & 4 & 2 \\
\hline \multirow{18}{*}{ Inclusion } & Activation & & 1 & 4 \\
\hline & \multirow{2}{*}{ Passivation } & Subjected social & 1 & - \\
\hline & & Beneficialized social actors & - & - \\
\hline & Genericization & & 7 & 3 \\
\hline & Specification & Individualization & 4 & 5 \\
\hline & & Assimilation & - & - \\
\hline & & Aggregation & - & 3 \\
\hline & & Collectivization & 4 & 5 \\
\hline & Association & & - & - \\
\hline & Dissociation & & - & - \\
\hline & Indetermination & & - & - \\
\hline & Differentiation & & - & - \\
\hline & Nomination & & 5 & 6 \\
\hline & Categorization & & 13 & 4 \\
\hline & Functionalization & & 1 & 2 \\
\hline & Identification & Classification & 11 & 7 \\
\hline & & Relational identification & 9 & 5 \\
\hline & & Physical Identification & - & - \\
\hline
\end{tabular}

In the movie Saint Jacques ... La Mecque (Figure 2; Figure 3), the societal roles of female characters are mothers, wives, and daughters. From the professional point of view, they are teachers and hosts. For instance, Clara, the main female character, is a daughter, mother, and sister and, from the functional point of view, a teacher, which is a traditionally female profession. If we reflect on her character, we can appreciate the combination of multiple functions and representations. Behind her rude face, she is considerate and shows a strong sense of responsibility. She is worried about her brothers and Ramzi, who she finally adopts after his mother's death. 


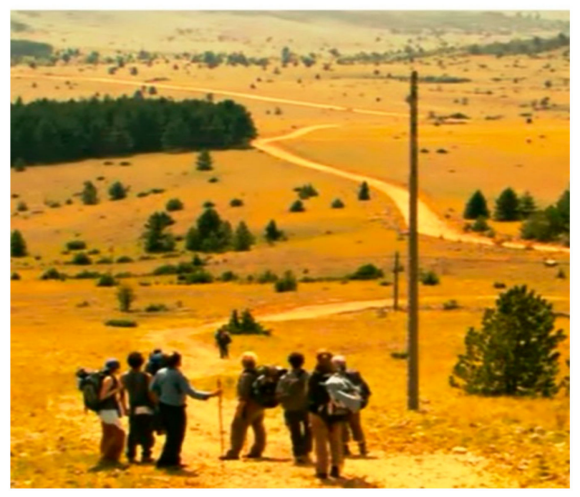

Figure 2. Rural Moviescape of the Camino.

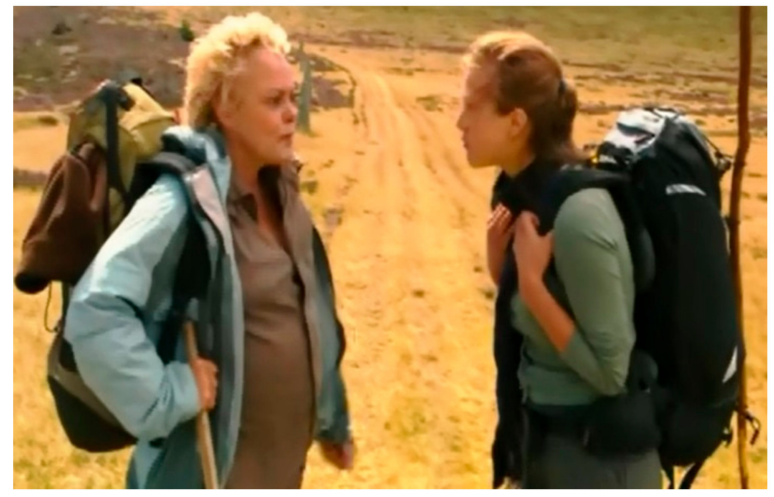

Figure 3. Clara and Camille discussing.

Figures 2 and 3 depict moviescapes representing the group pilgrimage. Figure 2 provides a view of the rural space of the Camino, whose snaking mark on the territory can be easily recognized. In Figure 2, the rural landscape of the Camino seems to be the main character, presenting the pilgrims with its essence and its challenges, aspects that pilgrims accept and seek $[13,87]$. A more detailed perspective is provided in Figure 3, where we see Clara (left) and Camille (right), who are pilgrims wearing comfortable clothing and carry their rucksacks. These female characters represent two age groups (adult vs. young), two social classes (middle class vs. rich), and two different perspectives and experiences that will determine their Camino.

\subsection{Movie 2: Al Final del Camino}

In Al final del Camino, Pilar (the female protagonist) is a journalist for a magazine. She has just broken up with her boyfriend, and her boss (Imma) orders her to write a report on the Camino. This is why she walks with Nacho, a photographer. As soon as they meet each other, they hate each other deeply. They will have to create a journalistic piece and approach the famous guru Olmo, who (to solve the couple's crises) proposes they walk Camino. This is an interesting aspect of the plot as it points out the multi-motivational aspect of the Camino and its emergence in new spiritual and therapeutic practices produced and reinforced by its rural landscapes [88]. Far from religious motivation, we witness a dynamic representation of the Camino, which provides spiritual renovation enhanced by the enjoyment of the landscape $[23,88]$. Far from their daily routines and in a completely different environment, the pilgrims challenge themselves. Pilar and Nacho have no choice but to accept the work and continue the pilgrimage together, pretending to be engaged. It is a sort of meta-relationship that is created in terms of couple dependence, as their professional roles will depend on their relational tasks [71].

Following Van Leeuwen's [80] methodology, social actors' representations can be classified as follows (Table 3): 
- Activation: The active female social actors are Pilar and her boss, Imma. Their active roles are maintained throughout the film. The main active male social actors are Nacho and the guru of the pilgrims' group. They are represented and usually referred to by what they do.

- Passivation: The five subject social actors are women. Two of them are not pilgrims, but they are described by means of a physical identification and as "very stupid girls". These actions are framed within scenes with sexual context. Within the group of the pilgrims, there are three women and six men. Two of them pretend to be homosexual, but their real intention is known to the girls, as occurs with the third social actor, who is a pilgrim. Each time she appears, there is a sexual allusion. Female pilgrims are the prey of the male social actors, as proven in the scene where two of the pilgrims try to get to know two female German pilgrims.

- Specification: This is obtained through individualization, with an unequal distribution of male (Nacho, Olmo, and Arturo) and female (Pilar and Imma) individualized social actors. The process of collectivization mainly concerns the pilgrims.

- Association: This refers to pilgrims who are considered entities.

- Indetermination: This refers to anonymous pilgrims.

- Nomination: Spectators know the names of the pilgrims of the group. The other characters are Imma and Arturo.

- Categorization: In terms of identities and functions shared with others, the dominant category is that of pilgrims.

- Identification: Concerning the relational identification, except for Pilar, the two other women of the group are wives, and the plot moves around their relationship with their husbands being in crisis. Within the status of pilgrims, the dominant categorization refers to wives and husbands or girlfriends and boyfriends. Thus, all the pilgrims of the group, apart from being recognized by their names, are classified as wife/girlfriend or husband/boyfriend.

Table 3. Cinematic discourse analysis in Al Final del Camino according to Van Leeuwen [80].

\begin{tabular}{|c|c|c|c|c|}
\hline & & & Female Characters & Male Characters \\
\hline Exclusion & Background & & 1 & - \\
\hline \multirow{18}{*}{ Inclusion } & Activation & & 2 & 5 \\
\hline & \multirow{2}{*}{ Passivation } & Subjected social & 5 & 1 \\
\hline & & Beneficialized social actors & - & - \\
\hline & Genericization & & - & - \\
\hline & Specification & Individualization & 2 & 3 \\
\hline & & Assimilation & - & - \\
\hline & & Aggregation & - & - \\
\hline & & Collectivization & 3 & 4 \\
\hline & Association & & 3 & 6 \\
\hline & Dissociation & & - & - \\
\hline & Indetermination & & 3 & 1 \\
\hline & Differentiation & & - & - \\
\hline & Nomination & & 4 & 6 \\
\hline & Categorization & & 6 & 5 \\
\hline & Functionalization & & 2 & 3 \\
\hline & Identification & Classification & - & 2 \\
\hline & & Relational identification & 4 & 3 \\
\hline & & Physical Identification & 2 & - \\
\hline
\end{tabular}

Source: own elaboration. 
Concerning this social status, the content analysis and the visual code show how the female social actors are represented as passive actors, especially in the sexual relationships, where they are the weakest partner. They are abandoned; they are harassed and used. As the female protagonist says: "You cannot use me all lifelong". Generally, they are represented as hysterical, confused, unsatisfied, liars, and unable to understand the situation (language, etc.). In Figure 4, Pilar (on the left) and Olmo (on the right) are talking; in the background, we see other pilgrims arriving. In Figure 5, the two pilgrims are brushing their teeth in a bathroom of a hostel along the route. Although it is a normal-seeming image, if analyzed deeper, the female pilgrim is younger than the male. Looking at the entire scene, this passage contains sexual allusion; once again the female pilgrim is the prey of the male pilgrim.

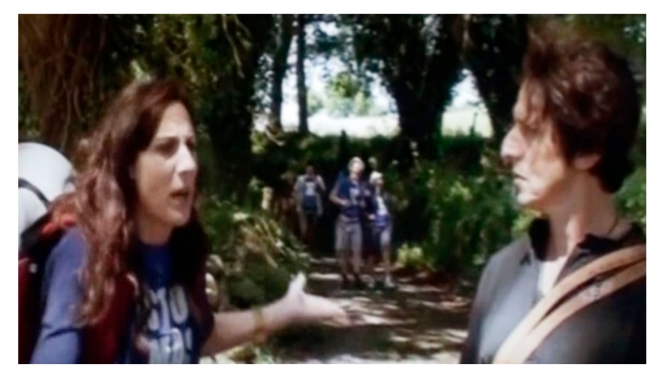

Figure 4. Imma and Olmo talking.

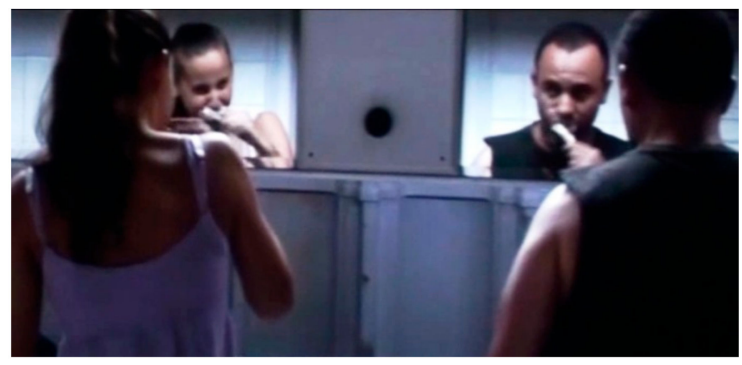

Figure 5. Pilgrims brushing their teeth.

\subsection{Movie 3: The Way}

In The Way, the protagonist is Thomas. He is an American ophthalmologist who travels to France due to the death of his son, Daniel. Daniel died while walking the Camino, when he had just began the journey. Although at the beginning Tom only intends to retrieve his son's body, he later decides to complete the pilgrimage to allow him to accomplish his son's goal. During his journey, he meets several pilgrims, and three of them become his companions.

Following Van Leeuwen's [80] methodology, the social actors' representations can be classified as follows (Table 4):

- Background: The background actors are relatives of Tom (mother and wife), Joost (wife and brother), and Sarah (husband).

- Activation: The male active social actors are Tom (the protagonist), the waiters, and the policemen. The female social actors are Tom's secretary, a waitress, and a host.

- Genericization: Two policemen are represented with generic references.

- Specification: This is achieved through individualization with three men and two women who are depicted as individuals. Collectively, the two communities represented here are that of the pilgrims (apart from the protagonist), containing three women and nine men. The other community is the gypsies, formed by various women and men, but counting them was difficult (apart from the boy who steals Tom's rucksack).

- Nomination: The four members of the group are identified by their names. Further nomination processes concern Tom's son (Daniel), Tom's friends, and Tom's patient and secretary. 
- Categorization: The represented social categories include hosts (a woman and a man), one waitress, and one secretary.

- Functionalization: Those who are referred to in terms of the function are Tom, Daniel, the police commander, and Jack (the Irish writer). There is no clear reference to the jobs of the female pilgrims; for instance, we do not know what Sarah does in terms of employment.

- Identification: The classification, which behind the general classification between Europeans and Americans, is mainly based on nationality. Each time pilgrims present themselves they state their origin. For instance, the group consists of three men from the USA, Ireland, and the Netherlands, and a woman from Canada. Concerning the relational identification, the most evident relation is that between Tom and his son Daniel, followed by that between Sarah's husband and Joost's wife.

Table 4. Cinematic discourse analysis in The Way according to Van Leeuwen [80].

\begin{tabular}{|c|c|c|c|c|}
\hline & & & Female Characters & Male Characters \\
\hline Exclusion & Background & & 3 & 2 \\
\hline \multirow{18}{*}{ Inclusion } & Activation & & 3 & 5 \\
\hline & \multirow{2}{*}{ Passivation } & Subjected social & - & - \\
\hline & & Beneficialized social actors & - & - \\
\hline & Genericization & & - & 2 \\
\hline & Specification & Individualization & 2 & 3 \\
\hline & & Assimilation & - & - \\
\hline & & Aggregation & - & - \\
\hline & & Collectivization & $\begin{array}{c}3 \\
\text { gypsies }\end{array}$ & $\begin{array}{c}9 \\
\text { gypsies }\end{array}$ \\
\hline & Association & & - & 3 \\
\hline & Dissociation & & - & - \\
\hline & Indetermination & & - & - \\
\hline & Differentiation & & - & \\
\hline & Nomination & & 3 & 4 \\
\hline & Categorization & & 3 & 1 \\
\hline & Functionalization & & - & 3 \\
\hline & Identification & Classification & 2 & 5 \\
\hline & & Relational identification & 1 & 3 \\
\hline & & Physical Identification & - & - \\
\hline
\end{tabular}

From a gendered point of view, the male social actors dominate (Figure 6). However, Sarah, the main female character, is initially mysterious and rude, although her other companions define her as "sexy", and do not reveal the real reason why Tom is walking the Camino. Her statement "European guys are too confident, so I prefer to leave" (minute 38) envisions a typical relationship between a man and woman, predator and prey. This stereotype is reinforced when she reveals that in her life before the Camino, she was married to an abusive husband. For her, the pilgrimage is an emotional chance to overcome her choice to have an abortion due to the husband who mistreated her. Thus, we are presented with a traditional image of a woman who is rather weak and cries when overcome by her problems (Figure 7). Figures 6 and 7 represent two different landscapes of the Camino: there is an outdoor cinematic landscape that serves the aesthetic principles of cinema due to its territorial richness and the magic atmosphere of faraway places $[26,59]$, and the inner landscape that pilgrims access due to the cathartic experience that they are living (Figure 7) [23,24]. 


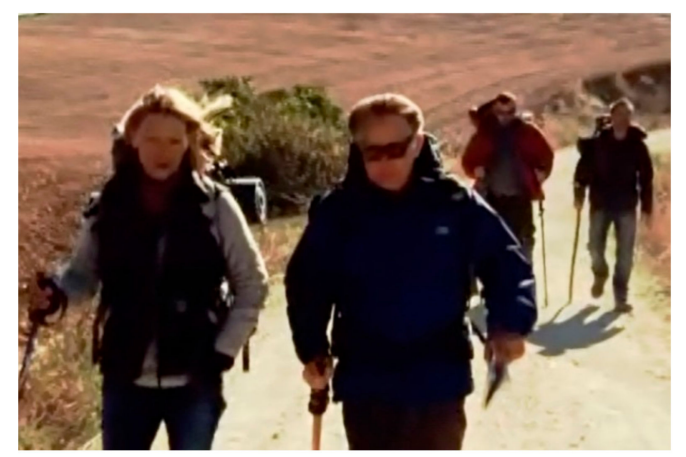

Figure 6. Pilgrims walking.

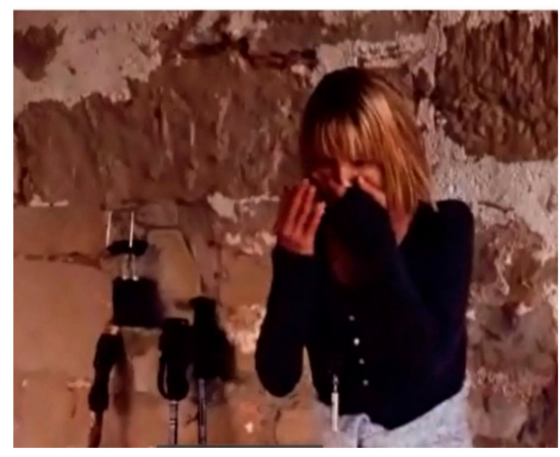

Figure 7. Sarah crying.

\subsection{Movie 4: Onde Eestá a Felicidade?}

In Onde está a Felicidade? the female protagonist, Theodora, learns that her husband (Nando) was maintaining a virtual relationship and is in crisis, resulting in the loss of her job as presenter of a culinary program (cooking competences are connoted as female). Disillusioned, she decides to walk the Camino, considered a journey of self-discovery. Her former boss suggests to her to make a reality show during the pilgrimage. Theodora makes a new friend, Milena, a Galician pilgrim who has been left by her Brazilian boyfriend; she decided to walk the Camino because she wants to become rich. During the pilgrimage, Theodora has a fun adventure, while Nando plans to win back her love.

Following Van Leeuwen's [80] methodology, social actors' representations can be classified as follows (Table 5):

- Activation: The professions represented in the film are those of Theodora and Bruno. The former is a TV show presenter; she is accompanied by her aesthetician and her technical assistant. Further active female roles are the hosts and the tourist office employees (as in Saint Jacques ... La Mecque). Apart from Zeca, Theodora's producer, the male active actors work with Nando in a TV sport program. The film is a proper activation process, as Zeca (the leader of the group) travels the Camino to produce a reality show based on Theodora's experience along the Camino.

- Passivation: The subjected social actors are mainly women, although they are not pilgrims.

- Genericization: This refers to an actor at the end of the film who pretends to be Theodora's Galician boyfriend.

- Specification: Individualization includes the protagonists and the main characters, Theodora, Milena, Zeca, and Bruno. They can be represented as specific, identifiable individuals for their professions and relational identifications.

- Collectivization: The two main kinds of communities are friends (three women and three men) and pilgrims (fifteen female pilgrims and nineteen male pilgrims). 
- Functionalization: The women represented according to their functions are Theodora and the host of the pilgrims' hostels. Men represented according to their function are Bruno, Zeca, and the theater actor.

- Identification: The relational identification refers to the couple, Bruno and Theodora, which is present throughout the entire plot. Then, at the end, we are introduced to Bruno's parents.

Table 5. Cinematic discourse analysis in Onde Está a Felicidade? according to Van Leeuwen [80].

\begin{tabular}{|c|c|c|c|c|}
\hline & & & Female Characters & Male Characters \\
\hline Exclusion & Background & & - & 2 \\
\hline \multirow{18}{*}{ Inclusion } & Activation & & 7 & 5 \\
\hline & \multirow{2}{*}{ Passivation } & Subjected social & 6 & - \\
\hline & & Beneficialized social actors & - & - \\
\hline & Genericization & & - & 2 \\
\hline & Specification & Individualization & 2 & 3 \\
\hline & & Assimilation & - & - \\
\hline & & Aggregation & - & - \\
\hline & & Collectivization & $\begin{array}{c}3 \text { friends } \\
15 \text { pilgrims }\end{array}$ & 9 gypsies \\
\hline & Association & & - & 3 \\
\hline & Dissociation & & - & - \\
\hline & Indetermination & & - & - \\
\hline & Differentiation & & - & \\
\hline & Nomination & & 4 & 4 \\
\hline & Categorization & & 2 & 1 \\
\hline & Functionalization & & 3 & 3 \\
\hline & Identification & Classification & - & 5 \\
\hline & & Relational identification & 3 & 3 \\
\hline & & Physical Identification & - & - \\
\hline
\end{tabular}

The visual analysis is centered on Theodora and Milena, who are usually accompanied by Zeca, a male guide (Figure 8; Figure 9). As shown by the moviescapes, their clothing differs from that of typical pilgrims and that used in the other movies. This shocking difference corresponds to the movie plot, which was constructed on a pilgrimage undertaken for a reality show, which is finally revealed as being a false pilgrimage. Thus, uncomfortable shoes, boots, pants, skirts, and heavy suitcases (full of useful objects typically used by women) reinforce the fictional dimension of the production. Clothes are communication tools that can be exploited to investigate how certain groups are categorized [89]. For this reason, these pilgrims become ridiculous and superficial, as is revealed in the final part of the movie. As shown in Figure 8; Figure 9, either from a semantic or an aesthetic interpretation, the contrasts between the rural landscapes of the Camino and the main characters are visible. Parts of the Camino, with its different natural and cultural aspects, are easier to walk than others, but the pilgrim-actors find themselves inadequate for the challenge of the Camino. Evidently, all of the technical choices correspond to the producer's intentions, which culminate in considering the Camino a serious experience that is not to be undertaken lightly. 


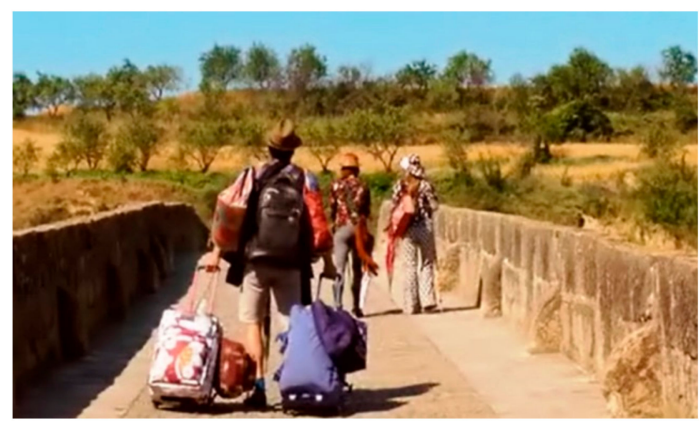

Figure 8. Zeca carrying the bags.

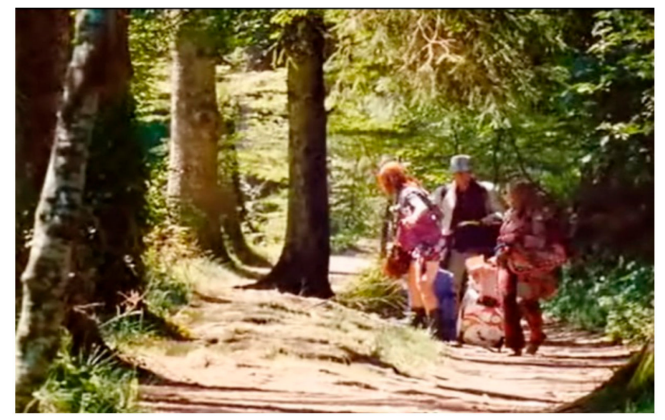

Figure 9. Pilgrims lost on the Camino.

\section{Discussion}

While statistical and quantitative data seem to indicate positive trends (Figure 1), and since rural spaces are not free from gendered relationships that might be imbued with stereotypes and unequal messages, the sources of the research present some allusions to the gendered visual representation of the Camino. The emotions evoked by the cinema are centered on spatial and social representations through the subjective experience that interferes with the meaning-making process. Although film locations correspond to real spaces, spatial representations are not completely neutral and objective. The more realistic the location, the more realistic the treatment of the characters. This was the focus of this research. The rural spaces of these visual narratives transmit their authenticity; therefore, attention should be paid to the social and gendered relationships that are represented, as "scenic spaces should convey the existence of a word with both an internal coherent logic" [38] (pp. 4359-4360). This respect for the natural and monumental environment has emerged in movies, which convey the idea of sustainable tourism along the Camino. As movies are also concerned with transmitting sensations and atmosphere about places [90], the immersive experience of the Camino has potential. Besides personal details, the background motivation of the movies is a proper quest, which is a spiritual journey that involves the search for one's self as part of an educational process of the individual [91,92]. The enjoyment of landscapes and environmental elements favor such physical and spiritual health $[20,23,24,87]$; thus pilgrims perceive the charm of the Camino, and are excited about what they are doing; a sort of "Camino effect" affects their vision. However, Honggang Xu [93] reminds us that public spaces are not innocuous and objectively defined, but are rather politicized, sexualized, subjective, and gendered. Additionally, Annette Pritchard and Nigel J. Morgan [72] warn that tourist landscapes are constructed as "masculinized" and built for the movement and enjoyment of men, often at the exclusion and isolation of women. Something similar emerges in the in the selected movies where, for instance, pilgrims' guides are always men, alluding to their role as leaders.

Each producer loads the space of the Camino with their poetics, that is, their personal discourse according to which some aspects are prioritized over others. The poïesis (meant as creative power) is contained in the poetic aspects of a space, the aim of which is to express a socio-spatial dimension [94]. This process engenders aesthetic representations and power relations, derived from a subjective and cultural understanding of the space within filming. For this reason, it was possible to identify the 
geo-poetics $[95,96]$ and a geo-politic $[97,98]$ of the Camino within the analyzed sources. The term geo-poetics denotes the multiple forms of representing the rural spaces of the Camino. The culture of origin, subjectivity, and experiences of the characters determine the transcultural representations of this pilgrimage route. The intensity of the geo-poetics depends on motivations, expectations, and ways of relating to the environment. In cinema, the setting, the places, and the décor have always represented some of the essential components of the production of a film. Thus, geo-poetics in the film production consist of understanding the cinematographic forms of the space that simultaneously provide a realistic framework for the action and the poetic support of a concrete and natural environment [99]. Geo-politics refers to representations, knowledge, and communications implied by this form of rewriting of the Camino rural space, as it produces relationships of knowledge and power between the creator and the observer [97,98]. For instance, the different modes of organization of the cinematic space enact political relationships that interpret the ideological issues related to the space. The motivation of the pilgrim-actors can determine the spectators' interpretations. Thus, also in the cinematic productions gender and sexuality are very much socially constructed through various power relationships $[91,100,101]$, although female pilgrims perform and embody the same practices of the male pilgrims. For C. Figueroa Domecq et al. [100], the studies on gender and tourism are important because they deal with a dynamic social phenomenon like tourism. The access of female tourists to touristic spaces and their experiences are subjected to the gaze of men, and therefore female tourists' experiences are highly influenced and often involuntarily altered by unwanted male attention and sexual harassment [101]. In the cinema, textual and visual codes have manifold ways to express the producers' intentions, while being imbued with the cultural knowledge that denotes the space of the Camino. Referring to the movies considered, styles are different, but all of them widely use the synecdoche, as the most common female social representations work as references for the whole genre. It was possible to identify the use of gendered stereotypes that (consciously or not) appear in the filmic productions. In addition, the female characters correspond to typical female social roles:

- The female protagonists and main characters are active social actors. Their professions are gendered stereotypes; for instance, Clara is a teacher (Saint Jacques ... La Mecque), Pilar is a journalist for a fashion magazine (Al Final del Camino), and Theodora (Onde Está a Felicidade?) is a cook.

- In the two comedies (Al Final del Camino and Onde Está a Felicidade), the female protagonists are victims of betrayal. In both cases, they decide to walk the Camino for professional reasons, and in both cases they are accompanied by a male colleague.

- Hosts of public and private hostels are played by actresses (Saint Jacques ... La Mecque, The Way, Onde Está a Felicidade?). Women work in pilgrims' offices (they sign the stamps or give the Compostelas once in Santiago). This is a characterization of female professions along the Camino.

- The diegetic analysis reveals that in three out of four films, female pilgrims' lives have been upset by a man (boyfriend or husband).

The comparison among the four movies revealed how the different treatments of the same cultural and territorial information rely on the use of filmic images as tools to construct a powerful (and successful) discourse. The real differences consist of the relationships between pilgrims and environment and between pilgrims and their Caminos. A different and more active representation of a female pilgrim was only found in the film produced by a female director-Saint Jacques ... La Mecque by Colin Serrau. The goal of feminist films to create other conditions of visibility for a different social subject [102] is achieved within the case studies, but the treatment of female characters still hides a certain degree of the patriarchal structure. The societal roles played by the female characters (wives, mothers, daughters, etc.) allude to the persistence of gender identities and models of representation that enable the exploration of the latent ideology within the abovementioned filmic productions. This reiteration occurs because tourism locations might not necessarily provide freedom from gendered social patterns [3]. The depicted female pilgrims are quite young, beautiful, and conform to the 
aesthetic canons, as the above moviescapes show (Figures 5-9). In the case studies, the cinematic production does not escape inequalities and discriminations. The images reproduced on the screen do not limit their effect to a target public; rather, they determine the perception of the societal and sexual roles [103].

\section{Conclusions}

The trend in movies and television shows whose messages penetrate society and determine choices about tourism destinations and behaviors has been growing [104]. Locations and movie experiences are enhanced in memories by associating them with actors, events, and settings $[48,50]$. In film productions, the representation of rural spaces and their transformation into locations have contributed to a process of renegotiation, producing multiple moving images with their cultural message. The cultural and creative industries, in general, and audiovisual content, in particular, are tools used to construct powerful and successful discourses that promote the values of the territorial identity resources (environment, landscape, history, local culture, and heritage) [7-9]. This recent age of cinematic production is contributing to renegotiating the space of the Camino, producing multiple moving images. The screen anticipates the pilgrimage experience, explaining its essence and acting as a dynamic travel guide [26]. Through these films, the viewer can access feelings and emotions in advance that might, eventually, lead to the desire to undertake the experience, walking the same spaces and sharing the same experiences. Filmic productions about the Camino deal with a cultural and historical location that is easily recognizable due to its international popularity. In so doing, movies intentionally reappropriate its space, which becomes a representational space. The different spatial interpretations and representations depend on the interests and aims of the producers, who use gendered stereotypes to empathize with their public. However, this use of gendered stereotypes in the artistic representations to convey a symbolic and generalized notion is ideologically and culturally dangerous in that it perpetuates and transmits a distorted representation of reality [89]. When shooting in the rural locations of the Camino, treatment and representation are not equal. The female pilgrims, or rather celluloid women, are young, aesthetically compliant, and must arouse the interest of men, thus once again the study pointed out the power structure that underlies equity and reveals that gender is socially constructed even in cultural industries. In other words, the cinema is not free from inequalities and discrimination [105]; this is an alarming finding that should encourage producers to reconsider the cinematic creation of female roles.

As recently stated by Rubén Lois González and Lucrezia Lopez [106] (p. 447): “the widespread access to cultural industries results in a proliferation of cultural products that interpret new forms of knowledge production, ranging from spatial characterization to significant geographical insights". The cinema is a form of social media and a social language of ideological content; it is a cultural production through which society takes the stage. As the Camino is attractive, it has earned the attention of many people. Cinematic production requires ethic production. Moreover, as the Camino involves spatial and cultural aspects, contemporary research on its narrative geographies needs to consider creative spaces like cinema that contributed to its spatial meaning-making process. According to the Countryside Commission [107], sustainability is one of the priorities of rural tourism development: "sustainable rural tourism consists in finding the correct harmony in the relationship established between the needs of the visitor, the place and the receiving community". In addition, gender equality is explicitly listed in the 17 sustainable development goals [108]; thus looking to the future, the desired harmony should be conceived as social and relational sustainability, meant as a formula to ensure equal gender treatment and representation of spatial discourses that ensure visibility, as is the case of the Camino. It is necessary to reinforce the gender perspective in pilgrimage studies to investigate the terms of women's participation and restore their image. With this purpose, this paper introduced a critical interpretation of the gendered stereotypes and patriarchal schemes of some filmic production along the Camino in order to support the need for social and relational sustainability in rural spaces. This approach was mainly based on exploring the social and functional relationships of the female pilgrims, 
although future interpretations might follow, such as those exploring corporal pilgrims' geography in cinema.

Funding: This research received no external funding.

Conflicts of Interest: The author declares no conflict of interest.

\section{Appendix A}

Table A1. Representing social actors. Van Leeuwen's [80] key concepts used for the cinematic critical discourse analyses.

\begin{tabular}{|c|c|c|c|}
\hline Exclusion & Backgrounding & \multicolumn{2}{|c|}{ Social actors are mentioned elsewhere, and we can infer who they are. } \\
\hline \multirow{17}{*}{ Inclusion } & Activation & \multicolumn{2}{|c|}{ Social actors are represented as the active and dynamic forces in an activity. } \\
\hline & \multirow[b]{2}{*}{ Passivation } & \multirow{2}{*}{$\begin{array}{l}\text { Represented as } \\
\text { "undergoing" the activity, } \\
\text { or as being "at the } \\
\text { receiving end of it". }\end{array}$} & $\begin{array}{l}\text { Subjected social actors are treated as objects in the } \\
\text { representation. }\end{array}$ \\
\hline & & & $\begin{array}{l}\text { Beneficialized social actors form a third party that, } \\
\text { positively or negatively, benefits from the action. }\end{array}$ \\
\hline & Genericization & \multicolumn{2}{|c|}{ Social actors can be represented by generic references (classes). } \\
\hline & \multirow[b]{3}{*}{ Specification } & \multirow{3}{*}{$\begin{array}{l}\text { Social actors are specific } \\
\text { and identifiable } \\
\text { individuals. }\end{array}$} & $\begin{array}{l}\text { Individualization: social actors can be referred to as } \\
\text { individuals. }\end{array}$ \\
\hline & & & $\begin{array}{l}\text { Assimilation: realized by plurality, mass nouns, and } \\
\text { nouns denoting a group of people. }\end{array}$ \\
\hline & & & 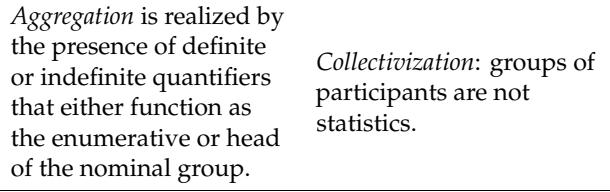 \\
\hline & Association & \multicolumn{2}{|c|}{$\begin{array}{l}\text { Groups formed by social actors and/or groups of social actors (either generically or } \\
\text { specifically referred to) who are never labeled in the text (although the actors or } \\
\text { groups who compose the association may themselves be named and/or categorized). }\end{array}$} \\
\hline & Dissociation & \multicolumn{2}{|c|}{ Associations are formed and unformed (“dissociation”). } \\
\hline & Indetermination & \multicolumn{2}{|c|}{$\begin{array}{l}\text { Occurs when social actors are represented as unspecified, "anonymous" individuals } \\
\text { or groups; determination is when their identity is, one way or another, specified. It is } \\
\text { typically realized by indefinite pronouns ("somebody," "someone," "some," "some } \\
\text { people") used in nominal function. }\end{array}$} \\
\hline & Differentiation & \multicolumn{2}{|c|}{$\begin{array}{l}\text { Explicitly differentiates an individual social actor or group of social actors from a } \\
\text { similar actor or group, creating the difference between the "self" and the "other," or } \\
\text { between "us" and "them". }\end{array}$} \\
\hline & Nomination & \multicolumn{2}{|c|}{$\begin{array}{l}\text { Social actors can be represented in terms of their unique identity by being nominated. } \\
\text { Nomination is typically realized by proper nouns, which can be formal, semiformal, or } \\
\text { informal. }\end{array}$} \\
\hline & Categorization & \multicolumn{2}{|c|}{$\begin{array}{l}\text { Social actors can be represented in terms of identities and functions they share with } \\
\text { others (categorization). }\end{array}$} \\
\hline & Functionalization & \multicolumn{2}{|c|}{ Social actors are referred to in terms of an activity (something they do). } \\
\hline & \multirow{3}{*}{ Identification } & \multirow{3}{*}{$\begin{array}{l}\text { Social actors are defined } \\
\text { according to what they are. }\end{array}$} & $\begin{array}{l}\text { Classification: Social actors are referred to in terms of } \\
\text { the major categories through which a given society or } \\
\text { institution differentiates between classes of people. }\end{array}$ \\
\hline & & & $\begin{array}{l}\text { Relational identification: represents social actors in terms } \\
\text { of their personal, kinship, or work relations to each } \\
\text { other. }\end{array}$ \\
\hline & & & $\begin{array}{l}\text { Physical Identification is always over-determined. } \\
\text { Physical attributes tend to have connotations, and } \\
\text { these can be used to obliquely classify or functionalize } \\
\text { social actors. }\end{array}$ \\
\hline
\end{tabular}

\section{References}

1. Acevedo Caradeux, D.; Gil Salom, L. Social Representation of Gender in Award-Winner Short Films in Spain. Procedia Soc. Behav. Sci. 2013, 95, 126-135. [CrossRef]

2. Lund, N.F.; Cohen, S.; Scarles, C. The Power of Social Media Storytelling in Destination Branding. J. Destin. Mark. Manag. 2017, 8, 271-280. [CrossRef] 
3. Whitson, R. Spaces of Culture and Identity Production: Home, Consumptions, and the Media. In Feminist Spaces: Gender and Geography in a Global Context; Oberhauser, A.M., Fluri, J.L., Whitson, R., Molett, S., Eds.; Routdledge: London, UK; New York, NY, USA, 2018; pp. 47-75.

4. Angelucci, D. L'insconcient optique comme «cinépotentialité»: Contingence et animisme du cinéma. Chimères 2016, 2, 36-47. [CrossRef]

5. Ethis, E. Sociologie du Cinéma et de ses Publics; Armand Colin: Paris, France, 2005.

6. Hurault-Paupe, A. The paradoxes of cinematic movement: Is the road movie a static genre? Miranda 2014, 10. [CrossRef]

7. Beeton, S. Film Induced Tourism, 2nd ed.; Channel View Publications: Clevedon, UK, 2016.

8. Nicosia, E. Cineturismo e Territorio: Un Percorso Attraverso i Luoghi Cinematografici; Pàtron Editore: Bologna, Italy, 2012.

9. Boccella, N.; Salerno, I. Creative Economy, Cultural Industries and Local Development. Procedia Soc. Behav. Sci. 2016, 223, 291-296. [CrossRef]

10. Liefooghe, C. Introduction général. L'économie créative et ses territoires: Nouvel enjeu, premiers bilans. In L'économie Créative et Ses Territoires; Liefooghe, C., Ed.; Presses Universitaires de Rennes: Rennes, France, 2015; pp. 9-24.

11. Gusman, I.; Lopez, L.; Lois González, R.C.; Santos Solla, X.M. The Challenges of The First European Cultural Itinerary: The Way to St. James. An Exploratory Study. Almatourism J. Tour. Cult. Territ. Dev. 2017, 8, 1-18. Available online: https://almatourism.unibo.it/article/view/6034. (accessed on 15 June 2020).

12. Lopez, L.; Santos Solla, X.M. Analysis of Territorial Development and Management Practices along the Way to St. James in Galicia. In Managing Religious Tourism; Wiltshier, P., Griffin, M., Eds.; CABI: Oxfordshire, UK, 2019; pp. 112-123.

13. Lois González, R.C. The Camino de Santiago and its contemporary renewal: Pilgrims, tourists and territorial identities. Cult. Relig. 2013, 14, 8-22. [CrossRef]

14. Santos Solla, X.M. Mitos y realidades del Xacobeo. Boletín AGE 1999, 28, 103-117.

15. Andrade Suarez, M.J.; Leira Landeira, G.; Caramés Valo, R. El Turismo como Factor Estratégicos de desarrollo rural: El Camino de Santiago Francés. ROTUR Rev. Ocio Tur. 2010, 3, 49-82.

16. Pardellas de Blas, X. O papel do turismo no desenvolvemento de es pacio rural. In O Turismo en Galicia: Potencialidades Endóxenas de Desenvolvemento Urbano e Económico; Hernández Borge, J., Díaz Fernández, J.A., Patiño Romaris, C.A., Eds.; Diputación Provincial de Pontevedra: Pontevedra, Spain, 2000; pp. 115-132.

17. Lois Gonzalez, R.; Lopez, L. El Camino de Santiago: Una aproximación a su carácter polisémico desde la geografía cultural y el turismo. Doc. Anàlisi Geogràfica 2012, 58, 459-479. [CrossRef]

18. Lois González, R.C. Dotaciones y infraestructuras del Camino de Santiago. Una aproximación geográfica. In Ciudades y Villas Camineras Jacobeas: III JORNADAS de Estudio y Debate Urbanos; López Trigal, L., Ed.; Universidad de León, Secretariado de Publicaciones: León, Spain, 2000; pp. 225-245.

19. Santos Solla, X.M. El Camino de Santiago: Turistas y Peregrinos hacia Compostela. Cuad. Tur. 2006, 18, 135-150.

20. Lois González, R.C.; Santos Solla, X. Tourists and pilgrims on their Way to Santiago. Motives, Caminos and final destinations. J. Tour. Cult. Chang. 2015, 13, 149-164. [CrossRef]

21. Pilgrims' Reception Office. Oficina del Peregrino. Santiago Pilgrim Office. Available online: www. archicompostela.org (accessed on 20 May 2020).

22. Moscarelli, R.; Lopez, L.; Lois González, R.C. Who is Interested in Developing the Way of Saint James? The Pilgrimage from Faith to Tourism. Religions 2020, 11, 24. [CrossRef]

23. Lopez, L.; Lois González, R.C.; Castro Fernández, B.M. Spiritual tourism on the way of Saint James the current situation. Tour. Manag. Perspect. 2017, 24, 225-234. [CrossRef]

24. Mikaelsson, L. Pilgrimage as Post-Secular Therapy. Scr. Inst. Donneriani Abo. 2012, 2, 259-273. [CrossRef]

25. Escudero Gómez, L.A. La Imagen Urbana de Santiago de Compostela (España), Un Estudio De Su Representación Pública, Mediática, Promocional Y Artística. Boletín Asoc. Geógrafos Españoles 2013, 62, 265-294. [CrossRef]

26. Lopez, L.; Nicosia, E.; Lois González, R.C. Sustainable Tourism: A Hidden Theory of the Cinematic Image? A Theoretical and Visual Analysis of the Way of St. James. Sustainability 2018, 10, 3649. [CrossRef]

27. Lopez, L.; Santomil Mosquera, D.; Lois González, R.C. Film-Induced Tourism in The Way of Saint James. Almatour. J. Tour. Cult. Territ. Dev. 2015, 6, 18-34. [CrossRef] 
28. Rodríguez Campo, M.L.; Fraiz Brea, J.A. Consideraciones estratégicas para la promoción del Turismo en Galicia través del cine. Rev. Galega Econ. 2010, 19, 1-11.

29. Smith, A.T. Time Warp: Cinematic Pilgrimage to Lourdes and Santiago. Int. J. Relig. Tour. Pilgr. 2017, 5, 55-62. [CrossRef]

30. Henderson, K.A. Broadening an Understanding of Women, Gender and Leisure. J. Leis. Res. 1994, $26,1-7$. [CrossRef]

31. Henderson, K.A. Feminist Leisure Studies: Origins, Accomplishments and Prospects; Routledge: London, UK, 2013.

32. Swain, M. Gender in tourism. Ann. Tour. Res. 1995, 22, 247-266. [CrossRef]

33. Esquenazi, J. L'Interprétation du film. In Approach to Film and Reception Theories: Cinéma et Théories de la Réception; Gelly, C., Roche, D., Eds.; Presses Universitaires Blaise Pascal: Clermond Ferrand, France, 2012; pp. 55-71.

34. Lane, B. What is Rural Tourism. J. Sustain. Tour. 1994, 2, 7-21. [CrossRef]

35. López Palomeque, F.; Vera Rebollo, J.F. Espacios y destinos turísticos. In Geografía de España; Gil Olcina, A., Gómez Mendoza, J., Eds.; Ariel: Barcelona, Spain, 2001; pp. 545-571.

36. Sparrer, M. Turismo No Espazo Rural e Desenvolvemento; Xunta de Galicia: Santiago de Compostela, Spain, 2007.

37. Saarinen, J. Critical Sustainability: Setting the Limits to Growth and Responsibility in Tourism. Sustainability 2014, 6. [CrossRef]

38. Figuereido, C. Narrative and visual cinematic strategies in communication design. Procedia Manuf. 2015, 3, 4358-4361. [CrossRef]

39. Friedmann, G.; Morin, E. Sociologie du cinéma. Rev. Int. Film. 1952, 10, 20-24.

40. Metz, C. Film Language: A Semiotics of the Cinema; Taylor, M., Translator; Oxford University Press: New York, NY, USA, 1974.

41. Kracauer, S. De Cagliari á Hitler: Une Histoire du Cinéma Allemand: 1919-1933; Flammarion: Paris, France, 1973.

42. Morin, E. Le Cinéma ou L'homme Imaginaire: Essai D'anthropologie Sociologique; Éditions Minuit: Paris, France, 1958.

43. Sorlin, P. Sociologie du Cinéma; Aubier Montaigne: Paris, France, 1977.

44. Desbois, H.; Gervais-Lambony, P.; Musset, A. Géographie: La fiction «au cœur». Ann. Géographie Géographie Fict. Réalisme 2016, 709, 235-245. [CrossRef]

45. Gámir Orueta, A. Del cine unipantalla al megaplex. Transformaciones recientes en la industria de la exhibición cinematográfica en España. An. Geogr. Univ. Complut. Madr. 2002, 21, 223-253. Available online: https://revistas.ucm.es/index.php/AGUC/article/view/AGUC0101110223A/31257 (accessed on 15 May 2020).

46. Gámir Orueta, A.; Manuel Valdés, C. Cine y Geografía: Espacio Geográfico, Paisaje y Territorio en las Producciones Cinematográficas. Boletín 2007, 45, 157-190. Available online: https://bage.age-geografia.es/ ojs/index.php/bage/article/view/643 (accessed on 10 May 2020).

47. Vergara Ovando, F. El cine, una herramienta para la compresión geográfica. Rev. Geográfica Valpso 2014, 49, 80-97.

48. Iwashita, C. Media representation of the UK as a destination for Japanese tourists: Popular culture and tourism. Tour. Stud. 2006, 6, 59-77. [CrossRef]

49. Kim, S.S.; Agusa, J.; Lee, H.; Chon, K. Effects of Korean television dramas on the flow of Japanese tourists. Tour. Manag. 2008, 28, 1340-1353. [CrossRef]

50. Riley, R.; Baker, D.; van Doren, C.S. Movie Induced Tourism. Ann. Tour. Res. 1998, 25, 919-935. [CrossRef]

51. Tooke, N.; Baker, M. Seeing is believing: The effect of film on visitor numbers to screened locations. Tour. Manag. 1996, 17, 87-94. [CrossRef]

52. Said, E. Orientalism; Vintage Book Editions: New York, NY, USA, 1979.

53. Tuan, Y.F. Humanistic Geography. Ann. Assoc. Am. Geogr. 1977, 66, 266-276. [CrossRef]

54. Eetvelde, V.V.; Antrop, M. The significance of landscape relic zones in relation to soil conditions, settlement pattern and territories in Flanders. Landsc. Urban Plan. 2005, 70, 127-141. [CrossRef]

55. Lefebvre, H. The Production of Space; Blackwell: Oxford, UK, 1991.

56. Rorty, R. Philosophy and the Mirror of Nature; Blackwell: Oxford, UK, 1980.

57. Bauer, S. L'Himalaya à Paris. Espace d'André Velter. In Scénarios d'Espace: Littérature, Cinéma et Parcours Urbains; Nitsch, W., Dünne, J., Eds.; Presses Universitaires Blaise Pascal: Clermont Ferrand, France, 2015; pp. 197-216. 
58. Hernández Ramírez, J. Turismo inducido. La configuración de la imagen turística de Sevilla a través del cine comercial. In Congr. Internacional Patrimonio, Desarrollo Rural y Turismo en el Siglo XXI; Universidad de Sevilla: Osuna, Spain, 2004.

59. Escher, A. The Geography of Cinema. A Cinematic World. Erdkunde 2006, 60, 307-314. [CrossRef]

60. Stoller, R. Sex and Gender; Hogarth: London, UK, 1968.

61. Oakley, A. Sex, Gender and Society; Temple Smith: London, UK, 1972.

62. Hubier, S.; Le Vaguaresse, E. Préface. In Gender et Séries Télévisé; Hubier, S., Le Vaguaresse, E., Eds.; Épure: Reims, France, 2016; pp. 5-15.

63. Domosch, M.; Seager, J. Putting Women in Place: Feminist Geographers Make Sense of the World; Guilford Press: New York, NY, USA, 2001.

64. Oberhauser, A.M.; Fluri, J.L.; Whitson, R.; Molett, S. Engaging Feminist Spaces: Introduction and Overview. I. In Feminist Spaces: Gender and Geography in a Global Context; Oberhauser, A.M., Fluri, J.L., Whitson, R., Molett, S., Eds.; Routdledge: London, UK; New York, NY, USA, 2018; pp. 1-24.

65. Massey, D. For Space; SAGE Publication: London, UK, 2005.

66. Walby, S. Theorizing Patriarchy; Basil Blackwell: Cambridge, UK, 1990.

67. Wolfenstein, M.; Leites, N. Movies: A Psychological Study; The Free Press: Glencoe, UK, 1950.

68. Haskell, M. From Reverence to Rape: The Treatment of Women in the Movies; University of Chicago Press: Chicago, IL, USA, 1973.

69. Rosewarne, L. The men's gallery: Outdoor advertising and public space: Gender, fear, and feminism. Women's Stud. Int. Forum 2005, 28, 67-78. [CrossRef]

70. Mulvey, L. Visual Pleasure and Narrative Cinema. Screen 1975, 16, 6-18. [CrossRef]

71. Butler, J. Gender Trouble: Feminism and the Subversion of Identity; Routdledge: London, UK; New York, NY, USA, 1990.

72. Pritchard, A.; Morgan, N.J. Constructing tourism landscapes-Gender, sexuality and space. Tour. Geogr. 2000, 2, 115-139. [CrossRef]

73. Vizcaíno Suárez, L.P.; Serrano Barquín, R.; Cruz Jiménez, G.; Pastor Alfonso, M.J. Theories and Methods in Research on Tourism Gender and Women in Ibero-America: A Bibliographic Analysis. Cuad. Tur. 2016, 38, 595-599. Available online: https://revistas.um.es/turismo/article/view/271531/200101 (accessed on 15 June 2020).

74. Geldsetzer, S. Towards a Definition of Women Crusaders to the Near East. In Femmes et Pèlerinages: Women and Pilgrimages; Dor, J., Henneau, M., Eds.; Compostela Group of Universities: Santiago de Compostela, Spain, 2007; pp. 47-56.

75. Heene, K. The Latin discourse on Women and Mobility in the Late medieval law Countries. In Femmes et Pèlerinages: Women and Pilgrimages; Dor, J., Henneau, M., Eds.; Compostela Group of Universities: Santiago de Compostela, Spain, 2007; pp. 153-190.

76. Esquenazi, J.P. L'analyse de Film Avec Deleuze; CNRS Editions: Paris, France, 2017.

77. Vancheri, L. Film, Forme, Théorie; Editions Le Harmattan: Paris, France, 2002.

78. Ferro, M. Cinéma et Histoire; Denoel-Gonthier: Paris, France, 1977.

79. Joly, M. Introduction à L'analyse de L'image; Armad Colin: Paris, France, 2015.

80. Van Leeuwen, T. Discourse and Practice; Oxford University Press: Oxford, UK, 2008.

81. Fairclough, N. Analysing Discourse: Textual Analysis for Social Research; Routledge: London, UK, 2003.

82. Fowler, R. Language in the News; Routledge: London, UK; New York, NY, USA, 1991.

83. Fowler, R.; Hodge, B.; Kress, G.; Trew, T. Language and Control; Routledge: London, UK; Kegan Paul: London, UK, 1979.

84. Kress, G.; Hodge, R. Language as Ideology; Routledge: London, UK; Kegan Paul: London, UK, 1979.

85. Dijk van, T. El análisis crítico del discurso. Anthropos 1999, 186, 23-36. Available online: http://www. discursos.org/oldarticles/El\%20an\%E1lisis\%20cr\%EDtico\%20del\%20discurso.pdf (accessed on 15 May 2020). [CrossRef]

86. Richardson, R. Literature and Film; Indiana University Press: Bloomington, IN, USA, 1970.

87. Kurrant, C. Biographical Motivations of Pilgrims on the Camino de Santiago. Int. J. Relig. Tour. Pilgr. 2019, 7, 11-18. Available online: https://arrow.tudublin.ie/ijrtp/vol7/iss2/3/ (accessed on 15 May 2020).

88. Kim, H.; Yilmaz, S.; Ahn, S. Motivational Landscape and Evolving Identity of a Route-Based Religious Tourism Space: A Case of Camino de Santiago. Sustainability 2019, 11, 3547. [CrossRef] 
89. Fluri, J. The Body, Performance and Space. In Feminist Spaces: Gender and Geography in a Global Context; Oberhauser, A.M., Fluri, J.L., Whitson, R., Molett, S., Eds.; Routdledge: London, UK; New York, NY, USA, 2018; pp. 25-46.

90. Mata Olmo, R. Introducción. In Atlas de los Paisajes de Castilla- La Mancha; Pons Giner, B., Ed.; Universidad de Castilla-La Mancha: Ciudad Real, Spain, 2011; pp. 10-19.

91. Morinis, A. Sacred Journeys: The Anthropology of Pilgrimage; Greenwood Press: Westport, CT, USA, 1992.

92. Turner, V.; Turner, E. Image and Pilgrimage in Christian Culture; Colombia University Press: New York, NY, USA, 1978.

93. $\mathrm{Xu}, \mathrm{H}$. Moving toward gender and tourism geographies studies. Tour. Geogr. 2018, 20, 721-727. [CrossRef]

94. Dell'Agnese, E.; Amilhat Szary, A. Borderscapes: From Border Landscapes to Border Aesthetics. Geopolitics 2015, 20, 4-13. [CrossRef]

95. Bachelard, G. La Poétique de L'espace; Les Presses Universitaires de France: Paris, France, 1957.

96. Paül i Carril, V.; Trillo Santamaría, J.M. Discussing the Couto Mixto (Galicia, Spain): Transcending the territorial trap through borderscapes and border poetics analyses. Geopolitics 2015, 20, 56-78. [CrossRef]

97. Minca, C.; Bialasiewicz, L. Spazio e Politica: Riflessioni di Geografia Critica; CEDAM: Padova, Italy, 2004.

98. Raffestin, C. Pour une Géographie du Pouvoir; Litec: Paris, France, 1980.

99. Gaudin, A. L'Espace Cinématographique: Esthétique et Dramaturgie; Armand Colin: Paris, France, 2015.

100. Figueroa-Domecq, C.; Pritchard, A.; Segovia-Péreza, M.; Morgan, N.; Villacé-Molinero, T. Tourism gender research: A critical accounting. Ann. Tour. Res. 2015, 52, 87-103. [CrossRef]

101. Brown, L.; Osman, H. The female tourist experience in Egypt as an Islamic destination. Ann. Tour. Res. 2017, 63, 12-22. [CrossRef]

102. De Lauretis, T. Alicia ya no: Feminismo, Semiótica, Cine; Cátedra: Madrid, Spain, 1992.

103. Rollet, B. Femme Set Cinéma, Sois Belle e Tait-Toi; Belin: Paris, France, 2017.

104. Butler, R.W. The Influence of the Media in Shaping International Tourist Patterns. Tour. Recreat. Res. 1990, 15, 46-53. [CrossRef]

105. De Los Reyes Lozano, J. La traduction du sexisme dans Mad Men, entre idéologie et restrictions. In Gender et Séries Télévisé; Hubier, S., Le Vaguaresse, E., Eds.; Épure: Reims, France, 2016; pp. 183-203.

106. Lois González, R.C.; Lopez, L. Liminality Wanted. Liminal landscapes and literary spaces: The Way of St. James. Tour. Geogr. Int. J. Tour. Space Place Environ. 2020, 22, 433-453. [CrossRef]

107. Countryside Commission. Sustainable Rural Tourism: A Guide to Local Opportunities; Countryside Commission: Cheltenhman, UK, 1995.

108. UN. Introduction and Proposed Goals and Targets on Sustainable Development for the Post 2015 Development Agenda; UN: New York, NY, USA, 2014; Available online: https://sustainabledevelopment.un.org/content/documents/ 4523zerodraft.pdf (accessed on 15 June 2020). 